\title{
Enjoyment of Statutory Employee Rights? A Myth or a Reality in Ghana?
}

\author{
Majoreen Osafroadu Amankwah ${ }^{1} \&$ Olivia Anku-Tsede ${ }^{1}$ \\ ${ }^{1}$ Department of Organisation and Human Resource Management (OHRM), University of Ghana Business School \\ (UGBS), Legon, Ghana \\ Correspondence: Majoreen Osafroadu Amankwah, Department of Organisation and Human Resource Management \\ (OHRM), University of Ghana Business School (UGBS), Legon, Ghana. Tel: 233-24-872-8245. E-mail: \\ maryeetey@ug.edu.gh \\ Received: May 31, 2013 \\ doi:10.5430/ijba.v4n6p145 \\ Accepted: October 18, 2013 \\ Online Published: November 8, 2013 \\ URL: http://dx.doi.org/10.5430/ijba.v4n6p145
}

\begin{abstract}
This study used empirical evidence to examine the extent of compliance with various labour regulations amongst private and public sector organisations. The study was conducted in Accra with data collected from 126 respondents between the period June and December, 2012. Accra was selected because it seats the headquarters of most organisations, where the HR unit is usually stationed. The study provided in-depth insight into the nature and extent of the violations of employee rights in Ghana. It suggests that whilst most HR managers complied with most of the provisions of the Labour Act, some provisions were ignored, in spite of its consequences. The findings of this study would help policy makers and regulators provide an effective mechanism to protect employee rights and ensure an effective compliance with labour regulations.
\end{abstract}

Keywords: employer, employee relations, employee rights, regulatory compliance, enforcement, human resource management

\section{Introduction}

Generally, human resource management (HRM) concerns all matters regarding an organisation's most valued asset, being its personnel as well as all issues arising out of the relationship between such personnel and the organisation. It often deals with matters arising from recruitment to terminations. HRM thus demands that, an organisation's most valued assets are properly managed so as to satisfy them continuously in order to realise the organization's goals since it is generally believed that satisfied employees are productive (Dessler, 2008; Belcourt and McBey, 2000). Employee needs are varied but most if not all can be satisfied at the workplace. The extent to which these needs are met can affect their behaviour on the job (Armstrong, 2009). Specifically, satisfaction of employees' needs could involve respecting their statutory rights so organisational goals can be realized.

To Belcourt and McBey, 2000; Mathis and Jackson, 2010, Çalişkan (2010), human resources are core competences that differentiate organisations from their competitors thereby creating sustainable competitive advantage, thus their proper and effective management is critical. This is more so now that competitive advantage based on human talent has become essential in today's "war for talent" (DelCampo, 2011). These sources of competitive advantage are also difficult to imitate within the shortest possible time. Though the proper management of employees is a shared responsibility between line managers and the human resource (HR) manager, the onus is more on the HR professional. Human resource managers perform several roles; one of which is being an advocate for employees. This, they do by ensuring that employee problems that are both work related and not work related are dealt with as this helps ensure fairness and equity (Mathis and Jackson, 2010; Noe et al, 2003). Without the HR advocacy role, employers could face even more lawsuits and regulatory complaints than they do now. According to the researchers, in lieu of the above benefit, irrespective of the level of the HR professional, he or she needs to have legal, administrative, and operational capabilities. Particularly, of prime interest is having legal capability because the relationship between employers/managers and employees must be handled legally and effectively, that is; employer and employee rights must be addressed. HR management is necessary especially due to the huge number of government regulations enacted over the past decades. However, the role of protecting corporate assets against the many legal issues often puts HR management in an enforcement role that may be seen as restrictive and administratively focused (ibid). 
Posited by Mathis and Jackson (2010), effective human resource management ensures that personnel and management practices conform to various regulations. Organisations have legal obligations to ensure that they are in compliance with laws governing the employer-employee relationship. Gomez et al (2007) have advanced that "compliance with the law is important because it is the right thing to do" and whether organisations find them relevant or not, they are mandatory. They however maintain that operating within the confines of the law provides benefits beyond simple legal compliance. For instance bad health and safety practices not only create a legal liability but also lead to poor employee morale and low job satisfaction which in the long run will affect job performance. This study therefore seeks to investigate the extent of employers compliance to various statutory provisions in the Ghanaian labour act (Act 651, 2003).

\section{Literature Review}

The HR function in organisations is becoming more strategic than it used to. This is more so because employees are now seen as sources of competitive advantage which are quite difficult to imitate. According to Belcourt and McBey (2000) "senior managers, investors, customers and HR professionals themselves make judgments in many ways about the effectiveness of the HR function". They further assert that the effectiveness of the human resource function can be assessed using the five (5) Cs model. This entails compliance, client satisfaction, culture management, cost control and contribution. Of critical importance to this research is the ability of the department to ensure legal compliance to various laws and regulations. Usually, line managers and top executives depend on the HR unit's expertise to ensure compliance with various legislations regulating the labour force. In Ghana, there are several laws including the 1992 Constitution, the Labour Act, 2003 (Act 651), Labour Regulations, 2007 (L.I. 1833), Factories, Offices \& Shops Act, 1970 (Act 328) and Workmen's Compensation Act, 1987 (PNDCL 187) as amended, all of which have provisions regulating the employment relationship. The organization cannot afford to tarnish its image due to violations of these laws hence one of HR's main responsibility is to ensure regulatory compliance.

In spite of the growing need for protecting employees' rights and ensuring compliance with relevant labour regulations by employers, some employers fail or refuse to comply with the labour regulations. It appears whilst some employers blatantly violate such regulations, others do so in ignorance. This may be because the National Labour Commission (NLC), an organization tasked to ensure compliance with the labour regulations, hardly lives up to expectations probably due to lack of human and financial resources. As noted by Gamey (2012), most people are in a haste to establish businesses without taking into consideration the institution of quality management systems to protect the workforce. Others also refuse to open any channels of communication to allow an efficient and effective resolution of claims arising out of such violations.

The above notwithstanding, there is to date no in depth studies in Ghana analyzing the extent and nature of the violations of employee rights, the impact of such rights violations on productivity and the role of HR in ensuring compliance with such regulations, particularly, in private and public sector organisations. This study therefore seeks to fill a gap in research by investigating issues of violations or compliance that have to date not been empirically investigated in Ghana.

\subsection{Relevance of the Legal Environment}

Gomez et al (2007) have indicated that compliance with employment laws is important for several reasons including helping the organization do the right thing, realizing the limitations of one's firm's HR and legal departments and minimizing ones potential liability. Keeping to employment laws is to mandate good management practice and more especially because operating within the laws has benefits beyond simple legal compliance. For instance, discrimination in the organization is not only wrong because it can create potential legal liability but can also lead to poor employee morale and low job satisfaction, which can in turn lead to poor job performance. They further reiterated that discriminating against qualified disabled employees makes no business sense as the organization hurts itself by not hiring the best. Organisations may also face public relations nightmare as it creates a negative image among customers or clients.

When laws are broken or perceived to be broken, financial liabilities are incurred which will ultimately affect the organisation's productivity. In the long run, these penalties cost businesses much more money than compliance (Ontario, Ministry of Labour, 2010). Thus when the HR department is able to work effectively, it acquires the tendency of keeping the organization out of trouble with the law which could also affect the bottom-line.

Central to ensuring regulatory compliance is good record keeping, writing and implementing good HR policies and monitoring the firm's HR decisions. It is also crucial that steps are taken to ensure that organizational policies do not contradict the various regulatory regimes (Gomez et al, 2007). For instance, the Labour Act of Ghana makes it mandatory for all employers to give a minimum of fifteen (15) working days annual leave to employees. It is thus the responsibility of the HR unit to ensure that the organization keeps to this by keeping abreast with current regulations 
as well as any subsequent amendments or repeals. Ensuring compliance is thus as crucial as being knowledgeable about the regulatory requirements at any given time. The use of proactive inspections and the establishment of an electronic complaints and investigations unit is equally important in ensuring regulatory compliance (Ministry of Labour, Ontario 2010).

\subsection{Models for Evaluation}

Several models are used in determining the effectiveness of HR's compliance and one of such is cost-benefit analysis which involves examining the relationship between the costs (direct and indirect) of a program and its benefits. The organization can calculate costs in keeping records, training managers on current laws, amongst others, as well as the benefits of favourable reputation and improved performance because compliance impacts positively on morale and satisfaction of employees. Periodic audits could also be conducted to ensure that HRM objectives are being met. It is known that audits can help identify gaps between actual and expected or desired results. For instance, where an organization has as its objective the reduction of the number of litigation due to violation, periodic audits could be carried out to determine whether this objective has been achieved, and if so the extent of success (Belcourt and McBey, 2000).

The labour laws of Ghana provide for certain labour practices and standards to govern the operations of employers as well as their responsibilities towards their employees. Some of these standards and practices include the provision of a satisfactory, safe and healthy conditions for workers; safe plant and system with no risk to health; safe and risk free handling, storage and transportation of articles and substances; necessary information, instructions, training and supervision to ensure health and safety at work; the prevention of the contamination of the workplace as well as the prevention of accidents and injury to health by minimizing the causes of hazards (Labour Act of Ghana, 2003).

In addition to the Labour Act of Ghana, there are also other international guidelines requiring the compliance with certain labour standards as well as ensuring that the rights of both men and women in employment or business are protected. International labour standards have thus become an important part of an agenda for ensuring that the rights of workers are safeguarded. It is worth noting that the International Labour Organisation (ILO) may not possess the relevant enforcement and sanctioning mechanism to compel compliance with some of these standards. These standards may however be binding on international parties or states who may have included them in their agreements or treaties. Some of the international labour standards cover issues such as freedom of association, collective bargaining, forced labour, equality of opportunity and treatment, wages, working time, occupational safety and health and maternity protection.

The areas of health and safety, union formation, rights and responsibilities of both employer and employee, engagement of minors, provision of all forms of paid holidays, employment of the disabled etc., are highly regulated. There is thus the need for a wake-up call on all organizations as the violation of any of these provisions can drag the company's name in the mud (Belcourt and McBey 2000). According to Belcourt and McBey (2000), "HR can make a difference by ensuring that managers and employees comply with the law, thus saving the company legal costs, fines and damaging publicity".

For instance, ensuring the health and safety of employees and the public at the workplace is both a legal and an ethical responsibility. The pain caused to employees due to accidents affects them and also creates a bad reputation for the organization. Manufacturing companies like Tema Steel, Tema Oil Refinery etc have been in the news for some time now concerning the frequency of accidents at their work places. In 2010, a simulation exercise ended up in a tragedy when one of the staff lost her life due to a worn out rope used during the exercise (Daily Graphic, 2010). According to the Labour Act of Ghana, employees have a right to the provision of free safety equipment whilst an employer is under a duty to provide such equipment. Ghanaian organisations with established human resource departments are responsible for ensuring compliance with the provisions of the law. If the HR unit is to be seen as strategic and contributing to the bottom line as other units, then they have to be up to the task of ensuring compliance of various laws governing the employment relations.

In spite of the existence of local labour regulations and international labour standards, some employers act contrary to and in clear violation of such labour regulations and standards. For instance in a research conducted on professional Ghanaian women, the outcome showed that most Ghanaian organizations make employees work for more than the stipulated eight hours provided for in the Labour Act of Ghana, with no overtime pay (Aryeetey et al, 2011). This clearly is in violation of the Labour Act of Ghana.

In spite of the importance of regulatory compliance in human resource management, there appears to be little or no in depth research that examines the nature and extent of compliance with regulations by employers in both public and private sectors. This study thus uses empirical evidence to analyse the nature and extent of regulatory compliance by employers. It evaluates the role of HR in ensuring an effective and efficient compliance with labour 
regulations as well as determine an appropriate mechanism for ensuring an effective redress in the event of an employee rights violation by an employer.

\section{Methodology and Methods}

The study was conducted in Accra in the Greater Accra region of Ghana between the period June and December, 2012. Accra was selected because it seats the headquarters of most organisations, where the HR unit is usually stationed. The study was exploratory and explanatory in nature. Exploratory research design provided background information which was used in planning the explanatory research. This design helped gain greater understanding of the problem for which more information was needed. The study also provided explanations on the nature of organizational compliance with the provisions in the Labour Act of Ghana, hence making explanatory design very appropriate. Explanatory research design is noted to be broader than descriptive research as its aim is to build theories and predict events. It equally has the goal of providing meaning as well as descriptions (McNabb, 2008).

The triangulation method was employed implying the use of both qualitative and quantitative methods. Qualitative research explores attitudes, behaviours and experiences which is core to the research problem hence the choice. Due to the nature of the research questions and hypotheses, both questionnaires (closed and open ended) and interviews (semi-structured) were utilized. A two section questionnaire was designed for non-managers. Section A covered the personal data while section B measured the extent of compliance to some sections of the Labour Act. Interviews (semi-structured) were conducted to solicit interpretations on the laws.

\section{Data Analysis}

Data gathered from the questionnaires were processed with the aid of Statistical Package for the Social Sciences (SPSS). The objectives were analyzed and presented in the form of tables, cross-tabulations, frequencies and percentages. Respondents were selected from both public and private institutions with organisations grouped into sectors for instance; banking and non-banking financial, educational, telecommunications, oil and gas etc. and samples selected to ensure fair representations. The population of the research comprised all private and public sector organisations in the capital of Ghana with a sample size of 126 respondents. A purposive sampling technique was used in generating organisations located in Accra where the respondents were selected. Even though Accra hosts the headquarters of most organisations, there are some other organisations which have no base in Accra at all. Thus, limiting the study to Accra may affect the generalization of the outcome of the research.

\section{Results and Discussions}

\subsection{Demographic Characteristics of Respondents}

A total of 126 filled questionnaires were used for the data analysis. The first part of the questionnaire sought to obtain the bio-data of the respondents. From the analysis, a total of 65 respondents $(51.6 \%)$ were males with the remaining $61(48.4 \%)$ being females, thus more males responded to the questionnaire than females. This is to be expected because men have traditionally been working in the corporate world long before women.

Respondents were required to indicate the industry type their organizations belong to. To simplify the analysis, open ended responses on industry type were aggregated into five main groups namely Banking and Finance, Services, Oil and Gas, Telecommunication and Education. $46 \%$ of the respondents were from the Banking and Finance industry; $28.6 \%$ from Services; $6.3 \%$ from Oil and Gas; $4.8 \%$ from telecommunications and $6.3 \%$ from Education. Results are presented in Table 1 below.

Table 1. Industry type of respondents

\begin{tabular}{lcc}
\hline Industry & Frequency & Percent \\
\hline Finance and Banking & 58 & 46.0 \\
\hline Services & 36 & 28.6 \\
\hline Oil and Gas & 8 & 6.3 \\
\hline Telecommunications & 6 & 4.8 \\
\hline Education & 8 & 6.3 \\
\hline Non Response (NR) & 10 & 7.9 \\
\hline Total & $\mathbf{1 2 6}$ & $\mathbf{1 0 0 . 0}$ \\
\hline
\end{tabular}

Source: Field Data, 2012 
Table 2 below gives a description of the industry from which the respondents were selected. Out of the 58 entities in the banking and finance sector, 29 each were public and private enterprises; Service sector entities were 36 in total with 23 being public and 13 private; Entities in the Oil and Gas sector were 8 in number with 6 being public and 2 private; Telecommunication entities were 6 in number with 4 being public and 2 private; the Education sector had 8 entities with 3 being public and 5 being private.

Table 2. Cross tabulation of Industry and ownership types

\begin{tabular}{llccc}
\hline & & \multicolumn{2}{c}{ Type of Ownership } & \multirow{2}{*}{ Total } \\
\cline { 3 - 5 } Industry & Finance and Bank & Public & Private & 58 \\
\cline { 2 - 5 } & Service/Utility Provider & 29 & 29 & 36 \\
\cline { 2 - 5 } & Oil and Gas & 23 & 13 & 8 \\
\cline { 2 - 5 } & Telecommunications & 6 & 2 & 6 \\
\cline { 2 - 5 } & Education & 4 & 5 & 8 \\
\hline Total & & $\mathbf{6 5}$ & $\mathbf{5 0}$ & $\mathbf{1 1 6}$ \\
\hline
\end{tabular}

Source: Field Data, 2012

\subsection{Nature of Employee Rights in Ghana}

The Labour Act, 2003 (Act 651) does not place any form of limitation or cup on the length of probation to be served by employees in Ghana. Specifically, the Labour Act refers to a "reasonable duration". More so the probationary period is generally provided in a collective agreement signed between the employer and the employee. $17 \%$ of the respondents indicated that they served a probationary period of $1-3$ months. Majority of the respondents (46\%) however indicated they served a probationary period spanning $4-6$ months; $28 \%$ of the respondents reported serving a probation period of $6-12$ months and $7.1 \%$ of the sample did not respond to the item. The varied nature of the probation period as presented in Table 3 below provides respondents representation on the length of probation period given to employees. This lays credence to the fact that the Labour Act of Ghana does not specify the duration of probation. It is thus often contractual.

Table 3. Length of probation for employees

\begin{tabular}{lcc}
\hline Duration & Frequency & Percent \\
\hline $1-3$ months & 22 & 17.5 \\
\hline $4-6$ months & 58 & 46.8 \\
\hline 6-12 months & 36 & 28.6 \\
\hline Non Response (NR) & 9 & 7.1 \\
\hline Total & $\mathbf{1 2 6}$ & $\mathbf{1 0 0 . 0}$ \\
\hline
\end{tabular}

Source: Field Data, 2012

Section 13 of the Labour Act stipulates that "Subject to the terms and conditions of a contract of employment between an employer and a worker, the employer shall within two months of the commencement of the employment furnish the worker with the written statement of particulars of the main terms of the contract of employment". Based on this, the study requested respondents to provide the duration within which their employers furnished them with written contracts. Although the law states clearly the duration, the analysis presented varied responses from the respondents. Specifically only $34.1 \%$ of the respondents mentioned that they received their contract letters within 2 months; $24.6 \%$ received their contracts within 6 months and $8.7 \%$ within 3 months. Surprisingly, about 5\% of the respondents indicated that they never received any form of contract from their employers. $27.8 \%$ were, however, non-responsive. The study therefore suggested that majority of employers do not comply with this provision in the Labour Act of Ghana. It further suggested that The National Labour Commission, the institution tasked to ensure compliance with the labour regulations in Ghana is probably not enforcing compliance with this basic rule.

To provide more insight into the duration of probation served by respondents, a cross tabulation between type of firm ownership and duration of probation was carried out. The results show that of the 58 respondents who indicated they served a probation spanning $4-6$ months, 30 of them were in publicly owned firms with 28 in privately owned firms; of the 36 respondents who served a probation period of $6-12$ months, 21 were in publicly owned firms and 15 in 
privately owned firms. 12 of the 22 respondents who indicated they were on probation for $1-3$ months were from publicly owned firms with the remaining 10 coming from privately owned firms. Table 4 below provides a representation of cross tabulation of public or private owned firms and duration of probation.

Table 4. Cross tabulation of public or private owned firms and duration of probation

\begin{tabular}{|c|c|c|c|c|c|c|}
\hline & & & How many mon & were you on & obation? & Total \\
\hline & & & 1-3 months & 4-6 months & 6-12 months & $10 t a t_{1}$ \\
\hline & & Count & 12 & 30 & 21 & 63 \\
\hline Public or Private & Public & $\begin{array}{l}\% \text { within Public or } \\
\text { Private }\end{array}$ & $19.0 \%$ & $47.6 \%$ & $33.3 \%$ & $100.0 \%$ \\
\hline 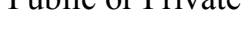 & & Count & 10 & 29 & 15 & 53 \\
\hline & Private & $\begin{array}{l}\% \text { within Public or } \\
\text { Private }\end{array}$ & $18.9 \%$ & $52.8 \%$ & $28.3 \%$ & $100.0 \%$ \\
\hline & & Count & 22 & 58 & 36 & 116 \\
\hline Total & & $\begin{array}{l}\% \text { within Public or } \\
\text { Private }\end{array}$ & $19.0 \%$ & $50.0 \%$ & $31.0 \%$ & $100.0 \%$ \\
\hline
\end{tabular}

Source: Field Data, 2012

\subsection{Union Formation}

Section 127 of the Labour Act stipulates the various kinds of discriminations regarding the formation or operations of labour unions by employers. For instance Section 127 (2) indicates clearly as an offense, should any individual or persons seek to intimidate or induce a worker to refrain from becoming or continuing to be a member or officer of a trade union.

The research sought to establish the extent to which management encouraged their workers to form labour unions from the view point of respondents. $54.8 \%$ of the respondents agreed that their management encouraged the formation of labour unions, however $19 \%$ of respondents disagreed. $20.6 \%$ of respondents indicated that they were not sure if their employers encouraged union formation. These results show that the management of some firms prevented their workers from unionizing. The study suggested that this may be because, unionization put forth a strong force on behalf of their membership, particularly in dealing with employee benefits and wage negotiations and that threatened most firms. They were thus uncomfortable encouraging workers to unionize. That notwithstanding, it is suggestive that the HR units of some firms were inactive.

It was further observed that $69(54.8 \%)$ of the total respondents agreed that their management encouraged union formation. Out of the 68 respondents, 45 of them were in publicly owned firms whilst 23 of them were in privately owned firms. 24 respondents disagreed that their management were accommodative of union formation; of these 14 were in publicly owned firms whilst 10 were in privately owned firms. 26 respondents were however not sure of their management's position as regards union formation; 8 of these respondents were from publicly owned firms whilst 18 were from privately owned firms. The outcome of this analysis shows that more publicly owned firms in the study area encouraged their employees to unionize compared to those in the private owned firms. Table 5 below shows a cross tabulation of organizational ownership type and attitude of management towards union formation.

Table 5. Cross tabulation of organizational ownership type and attitude of management towards union formation

\begin{tabular}{|c|c|c|c|c|c|c|}
\hline & & & \multicolumn{3}{|c|}{ My management encourages union formation } & \multirow[b]{2}{*}{ Total } \\
\hline & & & Agree & Disagree & Not sure & \\
\hline \multirow[t]{4}{*}{ Public or Private } & \multirow[t]{2}{*}{ Public } & Count & 45 & 14 & 8 & 67 \\
\hline & & $\begin{array}{l}\% \text { within Public or } \\
\text { Private }\end{array}$ & $67.2 \%$ & $20.9 \%$ & $11.9 \%$ & $100.0 \%$ \\
\hline & \multirow[t]{2}{*}{ Private } & Count & 23 & 10 & 18 & 51 \\
\hline & & $\begin{array}{l}\% \text { within Public or } \\
\text { Private }\end{array}$ & $45.1 \%$ & $19.6 \%$ & $35.3 \%$ & $100.0 \%$ \\
\hline Total & & Count & 68 & 24 & 26 & 118 \\
\hline
\end{tabular}




\begin{tabular}{|c|c|c|c|c|c|c|}
\hline & & & \multicolumn{3}{|c|}{ My management encourages union formation } & \multirow[b]{2}{*}{ Total } \\
\hline & & & Agree & Disagree & Not sure & \\
\hline \multirow[t]{4}{*}{ Public or Private } & Public & Count & 45 & 14 & 8 & 67 \\
\hline & & $\begin{array}{l}\% \text { within Public or } \\
\text { Private }\end{array}$ & $67.2 \%$ & $20.9 \%$ & $11.9 \%$ & $100.0 \%$ \\
\hline & Private & Count & 23 & 10 & 18 & 51 \\
\hline & & $\begin{array}{l}\% \text { within Public or } \\
\text { Private }\end{array}$ & $45.1 \%$ & $19.6 \%$ & $35.3 \%$ & $100.0 \%$ \\
\hline \multirow[t]{2}{*}{ Total } & & Count & 68 & 24 & 26 & 118 \\
\hline & & $\begin{array}{l}\% \text { within Public or } \\
\text { Private }\end{array}$ & $57.6 \%$ & $20.3 \%$ & $22.0 \%$ & $100.0 \%$ \\
\hline
\end{tabular}

Source: Field Data, 2012

Respondents were asked to indicate whether labour unions existed in their organizations. 61 respondents answered this question; of the 61 respondents, $14(11.1 \%)$ affirmed their organizations had labour unions whilst $40(31.7 \%)$ indicated their organizations did not have labour unions.

Respondents were further asked to indicate the number of unions that existed in their organizations as a follow-up question to the existence of unions in their organizations. In response to the above, $20.6 \%$ of respondents mentioned that their organization had only a single union; $27 \%$ of respondents mentioned their organizations had two (2) unions and $16.7 \%$ of respondents mentioned that their organizations had three (3) unions. $35.7 \%$ were non-responsive. It appears therefore that the provisions in the Labour Act of Ghana concerning multiple union formation are somewhat abided by organizations and that encouraged union formations.

\subsection{Provision of Leave}

On the issue of annual leave, even though $4.8 \%$ were non-responsive, most of the respondents, 108 out of 126 , representing $85.7 \%$ of the respondents were of the view that they were always entitled to their annual leave. A negligible number, 2 respondents, $(1.6 \%)$, indicated however that they were not entitled to their annual leave. Some of the respondents $(7.9 \%)$ were of the view that they were "sometimes" entitled to such leave. Section 20 (1) of the Labour Act of Ghana specifically states that "In an undertaking every worker is entitled to not less than fifteen working days leave with full pay in a calendar year of continuous service". The study showed that employers are largely complying with this requirement provided in the Labour Act, even though a few of the respondents (1.6\%) stated otherwise.

To further bring the issue of leave to fore, respondents were asked to state the number of leave days they are entitled to within their organization. The responses were varied and were thus streamlined into three (3) categories; leave spanning the duration of 1-15 working days, 16-30 working days and above 30 working days. The results as presented in Table 6 below show that most of the respondents (57.1\%) were entitled to leave days spanning 16-30 working days. This was followed by respondents who were entitled to leave days above 30 working days forming $32.5 \%$ of the total respondents. A few respondents $(4.8 \%)$ indicated that they, were entitled to leave days lasting the duration of 1 to 15 working days. Results imply that most organizations give more than the fifteen days minimum enshrined in the act. This is interesting because, employers benefit when they grant employees time off. Aside the fact that it has legal implications, health wise, employees return refreshed and are therefore able to expend their energies to enable the organization perform.

Table 6. Number of leave days

\begin{tabular}{lcc}
\hline & Frequency & Percent \\
\hline $1-15$ working days & 6 & 4.8 \\
\hline $16-30$ working days & 72 & 57.1 \\
\hline Above 30 working days & 41 & 32.5 \\
\hline Non Response (NR) & 7 & 5.6 \\
\hline Total & $\mathbf{1 2 6}$ & $\mathbf{1 0 0 . 0}$ \\
\hline
\end{tabular}

Source: Field Data, 2012 


\subsection{Provision on Hours of Work}

By law, employees in Ghana are mandated to work for a maximum of eight (8) hours a day or forty hours a week except in cases expressly provided for by the Act (Sec 33 of the Labour Act, 2003 (Act 651). To empirically establish the extent to which this is evident on the ground, the survey asked respondents to indicate how many hours they worked. The results show that $88(69.8 \%)$ of the 126 respondents, work for a total of eight hours as enshrined in the Act.

Approximately $20 \%$ of the respondents indicated that they worked for ten (10) hours a day. Respondents who worked for more than 10 hours constituted $6.3 \%$ of the total respondents. There was however some non-responses on the issue as presented in Table 7 below. In all, the results show some level of compliance with the eight (8) hours of daily work provided in the law. In the case of respondents who indicated they work for a duration above the 8 hours, the study can safely assume they fall under the "exceptional cases" category.

Table 7. Number of working hours in a day

\begin{tabular}{lcc}
\hline Working hours & Frequency & Percent \\
\hline 8 hours & 88 & 69.8 \\
\hline 10 hours & 25 & 19.8 \\
\hline 12 hours & 8 & 6.3 \\
\hline Non-Responses (NR) & 5 & 4.0 \\
\hline Total & $\mathbf{1 2 6}$ & $\mathbf{1 0 0 . 0}$ \\
\hline Sour
\end{tabular}

Source: Field Data, 2012

In Table 8 below, 87(69.8\%) respondents indicated that they work 8 hours daily. Of the 87 respondents, 43 of them were in publicly owned organisations whilst 44 of them were in privately owned organizations. 25 respondents indicated they worked 10 hours daily; 16 of these respondents were from publicly owned organizations whilst 9 of the respondents were from privately owned organizations. 8 respondents indicated also that they worked 12 hours daily; 7 of these respondents were in publicly owned organizations whilst only one respondent was from a privately owned organization.

Table 8. Cross tabulation between company ownership type and number of working hours

\begin{tabular}{|c|c|c|c|c|c|c|}
\hline & & & \multicolumn{3}{|c|}{ Number of working hours in a day } & \multirow[b]{2}{*}{ Total } \\
\hline & & & 8 hours & 10 hours & 12 hours & \\
\hline \multirow[t]{5}{*}{ Public or Private } & Public & Count & 43 & 16 & 7 & 66 \\
\hline & & $\%$ within Public or Private & $65.2 \%$ & $24.2 \%$ & $10.6 \%$ & $100.0 \%$ \\
\hline & Private & Count & 44 & 9 & 1 & 54 \\
\hline & & $\%$ within Public or Private & & & & \\
\hline & & & $81.5 \%$ & $16.7 \%$ & $1.9 \%$ & $100.0 \%$ \\
\hline \multirow[t]{3}{*}{ Total } & & Count & 87 & 25 & 8 & 120 \\
\hline & & $\%$ within Public or Private & & & & \\
\hline & & & $72.5 \%$ & $20.8 \%$ & $6.7 \%$ & $100.0 \%$ \\
\hline
\end{tabular}

Source: Field Data, 2012

In Table 9 below, a total of 66 respondents, representing 52.4\%, indicated they are not paid for working beyond the prescribed eight (8) hours by their employers. This outcome confirms a previous study by Aryeetey et al (2011) that most organizations do not remunerate employees who work beyond the stipulated time. Contrarily, $27.8 \%$ of the respondents confirmed that they are paid for working beyond eight (8) hours. A small number of respondents, $12.7 \%$ indicated they were sometimes paid for extra hours they spent on the job. 
Table 9. Are you paid when you work beyond the traditional 8 hours of work?

\begin{tabular}{lcc}
\hline & Frequency & Percent \\
\hline Yes & 35 & 27.8 \\
\hline No & 66 & 52.4 \\
\hline Sometimes & 16 & 12.7 \\
\hline Non-Response (NR) & 9 & 7.1 \\
\hline Total & $\mathbf{1 2 6}$ & $\mathbf{1 0 0 . 0}$ \\
\hline
\end{tabular}

Source: Field Data, 2012

Respondents were asked in the survey instrument to indicate if they were remunerated for working on public holidays. $50 \%$ of the total respondents indicated that they are remunerated for working on public holidays; $33.3 \%$ of respondents indicated that they were not paid and $10 \%$ indicated they are sometimes paid. Some of the respondents $(6.3 \%)$ did not respond to this question. Those organizations that do not compensate employees who worked on public holidays are contravening the provision in the act as the act provides for payment on such days. Table 10 below shows respondents responses to the issue of whether their employers remunerate them when they work on public holidays.

Table 10. Does your employer remunerate you when you work on public holidays?

\begin{tabular}{lcc}
\hline & Frequency & Percent \\
\hline Yes & 63 & 50.0 \\
\hline No & 42 & 33.3 \\
\hline Sometimes & 13 & 10.3 \\
\hline Non-Response (NR) & 8 & 6.3 \\
\hline Total & $\mathbf{1 2 6}$ & $\mathbf{1 0 0 . 0}$ \\
\hline Sour
\end{tabular}

Source: Field Data, 2012

5.6 Provisions on Women Issues

Most of the respondents, $70.6 \%$, indicated their firms grant them maternity leave spanning the duration of $1-3$ months and $9.5 \%$ indicated they are entitled to maternity leave of more than 3 months. Close to $20 \%$ of respondents did not answer this question as indicated in Table 11 below. This percentage could be men who might not be conversant with such issues.

Table 11. How many months of maternity leave do organizational members enjoy?

\begin{tabular}{lcc}
\hline Months & Frequency & Percent \\
\hline 1 -3 Months & 89 & 70.6 \\
\hline More than 3 Months & 12 & 9.5 \\
\hline Non-Response (NR) & 25 & 19.8 \\
\hline Total & $\mathbf{1 2 6}$ & $\mathbf{1 0 0 . 0}$ \\
\hline
\end{tabular}

Source: Field Data, 2012

Respondents were asked to indicate whether their organizations gave bonuses when female employees were on maternity leave. $38.9 \%$ of respondents indicated they were given bonuses; $49.2 \%$ indicated they were not given bonuses and $4.8 \%$ indicated they were sometimes given bonuses when on maternity leave.

Majority of the total respondents $(73.8 \%)$ indicated that nursing mothers (i.e. mothers with babies less than a year or a year old) were allowed to close before the normal closing time (after 8 hours). A small number, $7.9 \%$, were of the view that nursing mothers do not close earlier than the normal closing time and $4.8 \%$ indicated that nursing mothers were not always allowed to close earlier. Results thus show that even though most employers allow their employees nursing their babies to close earlier than the stipulated closing time, others do not practice this. Section 57 of the Labour Act of Ghana provides for the entitlements of workers during maternity leave. For example sub-section 6 states categorically that "A nursing mother is entitled to interrupt her work for an hour during her working hours to nurse her baby". Additionally sub-section (7) goes further to add that "Interruptions of work by a nursing mother for the purpose of nursing her baby shall be treated as working hours and paid for accordingly". It is therefore imperative for employers to ensure that the provision of the law is adhered to strictly. 
In response to whether sick leave is deducted from their annual leave, 106 respondents $(84.1 \%)$ indicated that their sick leave is not deducted from their annual leave; 5 respondents $(4 \%)$ answered in the affirmative and 11 respondents $(8.7 \%)$ mentioned they were not sure if their sick leave is deducted from their annual leave entitlement or not. $84.1 \%$ of the total respondents further indicated that they were given the opportunity to split their annual leave into two equal parts whilst $6.3 \%$ indicated they were not allowed to split their annual leave. It can therefore be deduced that most employers complied largely with these provisions in the act.

\section{Conclusion}

The study showed that there appears to be partial organizational compliance with provisions of the Labour Act of Ghana. Though the sampled organizations had HR departments which should be ensuring compliance, the study showed that only $34 \%$ of the sampled organizations furnished their employees with their employment contracts. In relation to union formation, the response was more than average, implying that most organizations kept to this provision. Though union formation is a right provided under law, only $11 \%$ of respondents had unions in their organizations. The findings however confirmed that multiple unions were formed in most Ghanaian organizations. Compliance to the provision regarding a minimum of fifteen working days annual leave was largely $(85.7 \%)$ adhered to. A worrying observation was that though women were granted maternity leave with pay, $49.2 \%$ indicated they were not given their bonuses, which were often not contractual. However, nursing mothers $(73 \%)$ were allowed to close before their required closing time. The study thus suggests that whilst most HR managers complied with most of the provisions of the Labour Act, some provisions were ignored, in spite of its consequences. As noted by Gomez et al (2009), non-compliance has the tendency of affecting staff morale, tarnishing the reputation of the organization and ultimately performance. Organizations that ignore adherence to provisions in the Act are likely to suffer the consequences in terms of morale, reputation and performance.

\section{Recommendation}

Following from the above, it is recommended that the various regulatory bodies, including the National Labour Commission, be vigilant and take steps to ensure strict compliance with the labour laws of Ghana.

\section{References}

Armstrong M. (2009). Handbook of human resource management practice. London: Kogan Page.

Aryeetey et al. (2011). Learning towards enabling work life balance for female professionals in Ghanaian organisations. Business \&Management Quarterly Review, 2(4), 1-13.

Belcourt, M., \& McBey, K. (2000). Managing Human Resources. Thomson Nelson, Ontario.

Çalişkan, Esra Nemli. (2010). The Impact Of Strategic Human Resource Management On Organizational Performance. Journal of Naval Science and Engineering, 6(2), 100-116.

Daily Graphic: Equip Fire Service Now. Retrieved September 14, 2010, from http://graphiceditorials.blogspot.com/2010/09/equip-fire-service-now-sept-14-2010.html

DelCampo R. G. (2011). Human Resource Management DeMystified. McGraw-Hill Companies Inc, USA.

Dessler, G. (2008). Human Resource Management ( $11^{\text {th }}$ ed). New Jersey: Prentice Hall.

Factories, Offices \& Shops Act. 1970 (Act 328).

Ghana Labour Law. (2003). Ghana labour act 651, 2003. Accra: Ghana Labour commission.

Gomez-Mejia et al. (2007). Managing Human Resources (5th ed.). Pearson Education, Inc, Upper Saddle River, New Jersey.

International Labour $\quad$ Organisation $\quad$ (ILO). $\quad$ Retrieved from http://www.ilo.org/global/standards/subjects-covered-by-international-labour-standards/working-time/lang--en/i ndex.htm

Labour Regulations. (2007). (L.I. 1833).

Mathis, R.L., \& Jackson, J.H. (2010). Human Resource Management. South-Western Learning, US.

McNabb, D.E. (2008). Research methods in Public Administration and Non Profit Management (2 ${ }^{\text {nd }}$ ed.). M.E Sharpe Inc, New York.

Noe et al. (2003). Human Resource Management: Gaining Competitive Advantage. McGraw-Hill/Irwin, New York.

Ontario, Ministry of Labour. (2010). Retrieved from http://www.labour.gov.on.ca/english/resources/notices.php 